\title{
The impact of water in architectural thinking
}

AKADÉMIAI KIADÓ

Pollack Periodica

An International Journal

for Engineering and

Information Sciences

$16(2021)$ 1, 138-144

DOI:

$10.1556 / 606.2020 .00131$

(c) 2020 The Author(s)

\section{ORIGINAL RESEARCH}

PAPER

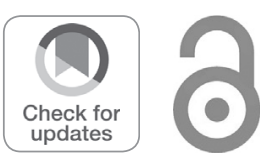

* Corresponding author.

E-mail: gabor.heckenast@gmail.com

\section{Gábor Heckenast $^{1 *} \odot$, Marcel Ferencz ${ }^{2}$ and András Tibor Kertész ${ }^{3}$}

${ }^{1}$ Marcel Breuer Doctoral School of Architecture, Faculty of Engineering and Information Technology, University of Pécs, Boszorkány u. 2, H-7624 Pécs, Hungary

${ }^{2}$ Ybl Miklós Faculty of Architecture and Civil Engineering, Óbuda University, Thököly út 74, H-1146 Budapest, Hungary

${ }^{3}$ Department of Architecture and Urban Planning, Institute of Architecture, Faculty of Engineering and Information Technology, University of Pécs, Boszorkány u. 2, H-7624 Pécs, Hungary

Received: December 23, 2019 • Revised manuscript received: May 1, 2020 • Accepted: May 4, 2020

Published online: February 4, 2021

\begin{abstract}
The focus of this research is the connection between architecture and water, how this natural element has formed the way of thinking. To give a complex answer, it is required to observe this complex topic from different aspects: time, space (with macro and micro space typology), meaning, technology, art and architectural design method, which all together can create a network of ideas. This outlined network could provide a theoretical basis for a new complex design method - from the building scale to the urban scale - for the upcoming challenges of built environment in connection with water in the future.
\end{abstract}

\section{KEYWORDS}

water, architecture, design method, urban planning, patterns, history

\section{INTRODUCTION}

The role of water in architecture is particularly significant, complex but above all unavoidable. The main question of this research is how did the presence of water influence the architectural mindset in connection with from small to large scale designs?

The research focuses not only on the physical relationship between water and the built environment, but also examines the impact of water on architecture. By examining and systematizing the relationships, the changes in the architectural mindset and the role of water in architecture can be traced. The main question of this research is how did the presence of water influence the architectural mindset in connection with from small to large scale designs?

Exploration of the different aspects can lead to understanding the potential and dangers of water in architectural terms, which offers additional opportunities under ever-changing circumstances and opening new avenues for design tasks, from architecture of buildings to urbanism.

\subsection{Tendencies}

It is a general tendency for growing cities to face new problems [1]. One of the complex problems is the provision of space for developments.

Several types of urban planning strategies have been developed and applied for this purpose: vertical expansion (high-rise buildings, vertical cities), horizontal expansion development of new neighborhoods [2] (to the detriment of the natural environment) and existing abandoned industrial areas (rehabilitation of deteriorated urban areas: new neighborhoods, city centers).

One of the big groups of architectural rehabilitation is the revitalization of former commercial or industrial areas, - which can be represented as architecturally valuable - and reintegrated into the life of the city, even as the center of a whole new quarter [3]. 
In many expanding cities in the horizontal sense, the former industrial zones have now been surrounded by the city, so that revitalized industrial areas form a bustling patch of the urban fabric.

These areas occupy a prominent position from the point of view of the city, because their former technological needs were influenced by the proximity of water. Depending on the technology used in the industrial area, the presence and availability of water was also a priority in the former installation.

\subsection{Former waterfront industrial areas}

Rehabilitation or rethinking of wasteland sites creates a new architectural quality, facilitating the connection between man, water and the built environment.

One possible way of rehabilitation is to revitalize - to add value to the existing function of the former industrial area, for example: Adventure Therapy Sailing School for Disabled and Non-Disabled Children - in the former industrial area of the Balatonfüred Shipyard, Hungary (Fig. 1) [4].

The Shackle Sailing School is an accessible water sports facility that everyone can enjoy without hindrance, and visit for discovery and love of the sport.

The name of the center is derived from the screw used in shipping equipment, which connects moving ship parts. "Shackle" is used as a visual metaphor to express the relationship between the built and natural environment, water and land, nature and man or man and man.

\section{WATER IN ARCHITECTURE AND ITS PERIPHERIES}

Water is manifested in many ways in architecture, in a variety of scales and forms - from the small scale to the urban scale. These may be artificial or natural water surfaces, which may also convey architectural intentions.

Not only the built environment is shaped by water, but also construction technology - building materials made with water technology and water itself can serve as building materials (e.g., an igloo or ice hotel) [5].

In the built environment water can perform a variety of functions, whether it is agricultural, commercial, military, medical, engineering, decorative, spiritual, or even an energy source.

In architectural terms, it can appear in many places in a building, either directly or indirectly. Directly, for example, in so-called algae facades, on green walls, and indirectly through various applied arts - like adapted water surfaces or Ned Kahn's kinetic facade cladding [6].

The indirect relationship between architecture and water is well illustrated by fluid architecture, where water is present as a space-shaping design principle, though not physically.

Architecture is organically complemented by waterrelated garden and landscape design, which facilitates environmental integration, and adds new layers to the architectural work, adding space to the water (Fig. 2).
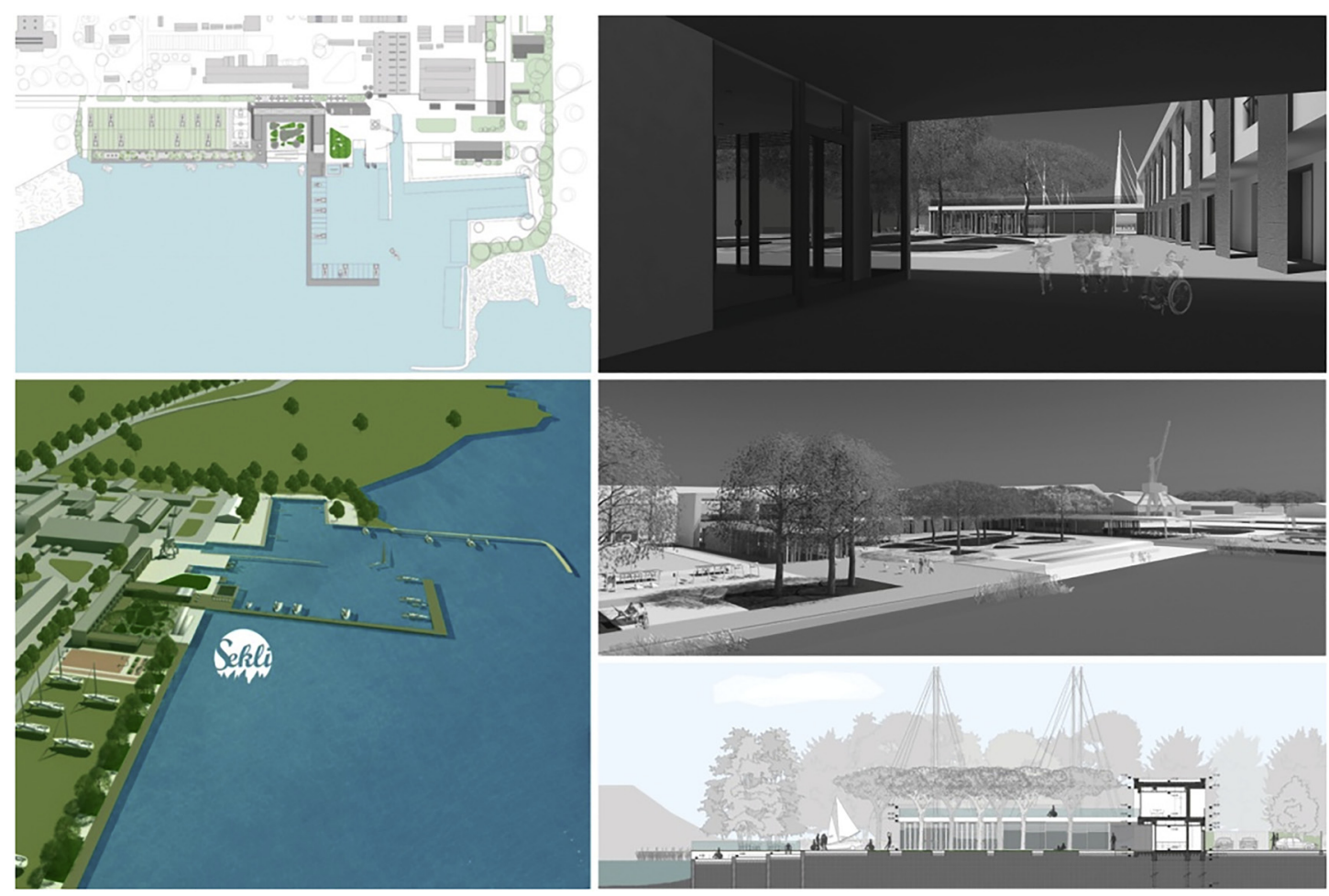

Fig. 1. Shackle adventure therapy sailing school for disabled and non-disabled children (Source: designed by: G. Heckenast) 


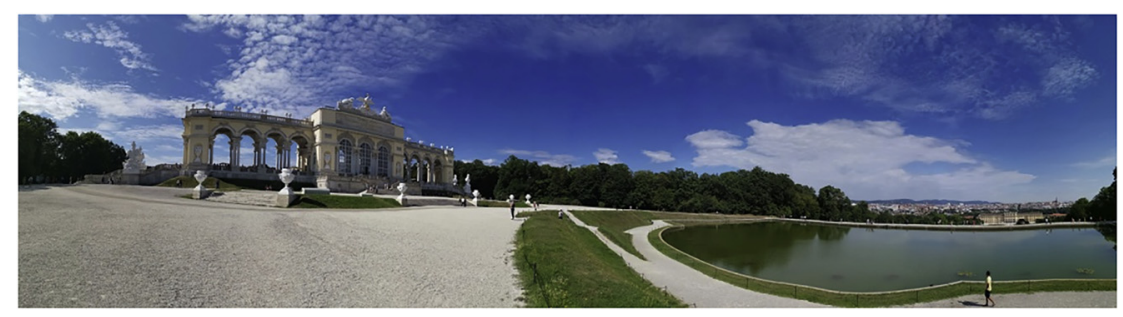

Fig. 2. Café Gloriette, Schönbrunn Palace, Vienna, Austria (Source: photo by G. Heckenast)

\section{THE PILLARS OF ARCHITECTURE}

By exploring the thought principles, new approaches and systems of consideration are brought to the fore. The fundamental question could be answered by examination of their relationships: How has the presence of water influenced the (architectural) mindset? The question implies the relationship of humans to water, of which only one segment is the architectural aspect.

Different architectural attitudes to water are due, in part, to the diversity of architecture, and partly to other subjective factors.

Architecture - construction is a complex task with many frontiers, which in itself results in a multitude of viewpoints. In a given spatial situation - be it a building, a set of buildings, an urban space - these different responses to the viewpoints form a coherent unique piece of architecture.

Due to the diversity of the topic, a multi-perspective approach is essential with the method of critical thinking. The relationship between water and architecture is worth exploring from historical, spatial, meaningful, technical, and artistic perspectives; providing a basis for exploring architectural design approaches (Table 1).

By examining the relationship between water and architecture from different aspects, through their context and relationships, the influence and importance of water in architectural thinking can be traced. In this way, this mapping of relationships can serve as a starting point for formulating new contemporary architectural responses to each design task - whether saving the built heritage,

Table 1. The pillars of architecture

\begin{tabular}{|c|c|c|c|c|}
\hline No & Pillars & Aspects & Main question & Description \\
\hline I. & Historical overview & Time & $\begin{array}{c}\text { How did water appear in } \\
\text { different periods of architectural } \\
\text { history? }\end{array}$ & $\begin{array}{l}\text { An overview of the inter- } \\
\text { relationships of architectural } \\
\text { history from the beginning to } \\
\text { the present day }\end{array}$ \\
\hline II. & Spatial connection system & Space & $\begin{array}{c}\text { How does water appear in the } \\
\text { built environment? }\end{array}$ & $\begin{array}{c}\text { Overview of spatial } \\
\text { relationships: Water surface } \\
\text { volume - Architectural scale. } \\
\text { examination of spatial formulas } \\
\text { from the urban scale to the living } \\
\text { space }\end{array}$ \\
\hline III. & Relative systems & Meaning & $\begin{array}{c}\text { How is one influenced by the } \\
\text { presence of water in the built } \\
\text { environment? Is water a measure } \\
\text { of well-being? }\end{array}$ & $\begin{array}{l}\text { The relationship between man, } \\
\text { architecture, and water from an } \\
\text { environmental psychological, } \\
\text { sociological, and cultural } \\
\text { anthropological perspective }\end{array}$ \\
\hline IV. & $\begin{array}{l}\text { Architecture-water-technology } \\
\text { relationship }\end{array}$ & Continuity of empiricism & $\begin{array}{c}\text { How can water be organized in } \\
\text { architecture? }\end{array}$ & $\begin{array}{l}\text { History of technological } \\
\text { development. Technical } \\
\text { solutions and conditions of } \\
\text { water usage in architecture. } \\
\text { A range of architectural and } \\
\text { technical solutions for } \\
\text { revitalizing built heritage. }\end{array}$ \\
\hline V. & $\begin{array}{l}\text { Architecture-water-art } \\
\text { relationship }\end{array}$ & World of ideas & $\begin{array}{l}\text { How did one of the most } \\
\text { influential environmental } \\
\text { elements influence culture? }\end{array}$ & $\begin{array}{c}\text { Water as a means of expression } \\
\text { in architecture and the arts, as } \\
\text { well as in periphery }\end{array}$ \\
\hline VI. & $\begin{array}{l}\text { Architectural design method and } \\
\text { water connection }\end{array}$ & $\begin{array}{l}\text { Water as an architectural } \\
\text { factor }\end{array}$ & $\begin{array}{c}\text { Which phase and how does water } \\
\text { appear during architectural } \\
\text { design? }\end{array}$ & $\begin{array}{l}\text { The tool of talent, need, } \\
\text { conceptual element, illusion - } \\
\text { architectural trends, } \\
\text { architectural theory }\end{array}$ \\
\hline
\end{tabular}


reinterpreting it, or creating a new architectural piece in the water environment.

\subsection{Historical overview}

Water plays a key role in human history. The relationship between the built environment and water has manifested itself in different forms in different periods of architectural history [7]. Settlements, residential bridges, water palaces, canals, and fountains when and how does water appear in the built environment?

Eventually, a set of developmental rules emerged from the totality of rules applied at different ages.

\subsection{Spatial connection system}

A large part of the earth's surface is covered by water, it is also present in the atmosphere, and even underground there are significant water resources, so inevitably water interacts with the built environment - from the smallest scale to the urban scale [3]. By exploring the relationship between architecture and water in spatial aspect and by defining types, parallels between the morphology of water and the built environment can be discovered (e.g., Venice - Amsterdam, Budapest - Vienna) (Fig. 3).

As a result, an overview of spatial relationships is outlined: water surface volume versus architectural scale; trough examination of spatial formulas from the urban scale to the living space.

\subsection{Relative systems}

Examining the relationship between the built environment and water from a human perspective: what environmental psychological, sociological, and cultural anthropological aspects and regularities influence the formation of the built environment in the presence of water [8].

Is water a measure of well-being? How does water influence the quality of architectural space? What aspects can be used to create a healthy-living space.

\subsection{Architecture - water - technology relationship}

Recognizing the laws that are essential to ensure our existence how has water become manageable in the built environment over time? How did the scientific approach in construction take over from the instinctive construction methods? Why is technology becoming indispensable in architecture, particularly when the presence of water increases?

This peculiar history of technological development [9] reveals the emergence of different techniques, and new ways and directions have become available in architecture transforming the architectural language as well. For example, the BMW Olympic Pavilion waterfall facade - as a living facade, or indirectly the green wall or algae facades, where water is a prerequisite.

\subsection{Architecture - water - art relationship}

Water as a means of expression in architecture: Water not only fulfills a need, it can also add meaning or creates a spatial illusion. Buildings and gardens form an integral whole, in which case water can serve as a conceptual bridge to the arts.

In the built environment, the artistic intention expressed in water interacts with several artistic disciplines (e.g., painting, sculpture, photography, film, etc.) [5], which abstract the water, thus adding new value to the architectural space.

\subsection{Architectural design methods and water connection}

The different answers to the basic water (nature) - architecture - human relationship question resulted in different architectural attitudes and mental tendencies [10, 11].

Different mentalities and trends of the time presented different architectural answers for each design task. By analyzing these rule-based responses, the relationship between architectural theory and water will be become more visible as design patterns.

For example, how did modern architecture relate to natural (Frank Lloyd Wright - Fallingwater House [12]) and artificial (Ludwig Mies van der Rohe - Barcelona pavilion [12]) water surfaces?

Water appears in architecture not only in its physical quality but also as a space-organizing principle (fluid spaces), as an abstract architectural element imitated water (e.g. wavy metal facade-installation by Ned Kahn [6]).

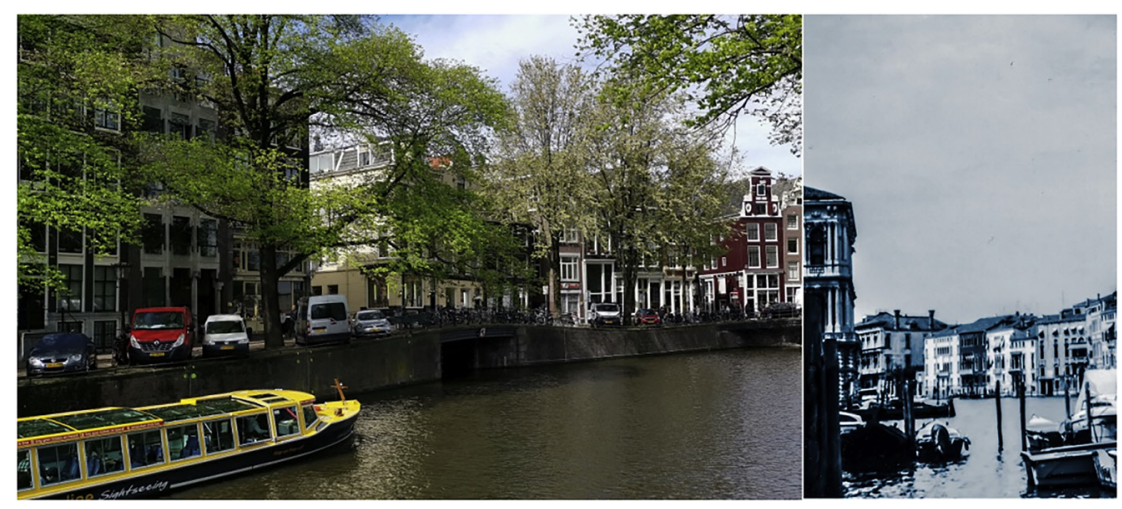

Fig. 3. Water cities: Amsterdam and Venice (Source: photo by G. Heckenast) 
The relationship to water in architecture is a complex issue: how the role of water in architecture is transformed and how architecture has responded through different ages and geographical locations.

In the history of mankind, the presence of water has always played a key role - in addition to the basic subsistence need - in economical, commercial, cultural and military terms. Architecture responded to these needs with a complex set of requirements and criteria.

The relationship between the built environment and water has been manifested in different forms in different eras of architectural history, thus eventually forming a complex system of rules which have been applied in different ages. The following table (Table 2) summarizes the waterrelated achievements of each architectural era, which were a milestone and thus greatly influenced the further development of the architectural mindset [7, 13].

There are several architectural responses to a water related problem posed which, in addition to meeting basic needs, appear as a subjective factor in architecture. This subjectivity gives character to architecture, making it lovable or not, recognizable or iconic - that can even re-position a city on the mental map of the individual.

The relationship of urban structures with water dates back a long time, to the first settlements. In order to understand the development process, it is possible to explore the structure of a city through its chronological typology of water, in relation to the location of the city. As urban water is easiest to typify, it is possible to trace what new approaches have been made to urban structures in each period of architectural history.

\section{TYPOLOGY}

The built environment near water can be grouped according to several criteria: state, behavior and cyclical patterns.

The state of the water can be gaseous (steam, mist, fog), liquid (lake, river, waterfall, rain), solid (ice, iceberg, glacier, hail), and crystalline (snow, avalanche) should determine how the built environment is designed.

The water-related environment can also be grouped according to how they mimic the behavior of water, which takes the form of imprints in the built environment: wavy facades (sea, ocean), flowing spaces (stream, river), crystalline mass formations (ice, icebergs), or transparent structures (rain, waterfall).

Time also could be an additional factor for further examination in the relationship between water and the built environment: the phenomenon of low tide, rising/decreasing - water levels, intermittent droughts, or even floods.

One of the most striking and fundamental issues is regarding its volume, which essentially determines the structural relationship of a city to water. Construction near water at locations like riverside, urban lakes, lakeside, coastlines, ocean-fronts, archipelagos, including residential bridges, and water palaces, all pose different design challenges.

The amount of water is organized in different shapes and ways within a city, basically defining the character of the city, such as: under the city, around the city, through the city, near the city, away from the city - but still visible (e.g., on a mountain nearby). In terms of spatial extent, it can be linear (1D: rivers), surface (2D: lakes) or a medium (3D: underwater).

Table 2. Architectural eras and water-related architectural inventions

\begin{tabular}{|c|c|c|c|}
\hline No & Architectural era & Architectural styles & Architectural inventions \\
\hline I. & Prehistoric times & $\begin{array}{l}\text { Megalithic architecture } \\
\text { Cave architecture } \\
\text { Ancient/tribal societies }\end{array}$ & $\begin{array}{l}\text { Reservoirs } \\
\text { River control }\end{array}$ \\
\hline II. & Ancient civilizations and antiquity & $\begin{array}{l}\text { Middle East, Far East } \\
\text { New World, Ancient Greek, Roman } \\
\text { Empire }\end{array}$ & $\begin{array}{l}\text { Water-conduit, sewerage sewer, bridges, water } \\
\text { mills, gardens, palaces baths, toilets }\end{array}$ \\
\hline IV. & Renaissance and Baroque & $\begin{array}{l}\text { Renaissance, Mannerism Baroque, } \\
\text { Rococo, Neoclassical, Revivalism }\end{array}$ & $\begin{array}{c}\text { Underground cisterns, Paris Opera House, } \\
\text { urban waste-water system, springhouses, } \\
\text { public utility, water castles, gardens }\end{array}$ \\
\hline V. & 19th century & $\begin{array}{l}\text { Eclecticism, Orientalism Beaux-Arts, } \\
\text { Art Nouveau, Industrial architecture }\end{array}$ & $\begin{array}{l}\text { Urban river control - urbanism, steel bridges, } \\
\text { industrial water, waterworks, engineering } \\
\text { facilities, steam engines, beam engine houses, } \\
\text { urban docks, palm houses }\end{array}$ \\
\hline VI. & Modern architecture & $\begin{array}{c}\text { Expressionist, Art Deco, International } \\
\text { Style, Bauhaus, Postmodern, } \\
\text { Deconstructivism }\end{array}$ & $\begin{array}{c}3 \mathrm{~F}-\text { form follows function, water } \\
\text { differentiation, new technological solutions, } \\
\text { flowing spaces }\end{array}$ \\
\hline VII. & Contemporary architecture & $\begin{array}{l}\text { The 21st century International, } \\
\text { contemporary trends }\end{array}$ & $\begin{array}{l}\text { New approach: water as a medium, new } \\
\text { technologies, environmental awareness, fluid } \\
\text { architecture, floating buildings }\end{array}$ \\
\hline VIII. & Futurology & Utopias, Research and development & $\begin{array}{c}\text { Water reinterpretation, swimming cities, } \\
\text { underwater cities }\end{array}$ \\
\hline
\end{tabular}


The groupings can be further subdivided into natural (rivers, lakes, seas, oceans) or artificial origins. Artificial waters include specific architectural and engineering structures: riverbed control, dams, canals, fountains, and water terraces.

Because of the complexity of the surrounding blue system, a number of typologies exist according to certain key characteristics (e.g., water related settlements, water usage [14]; river typology, and flood strategy $[10,15])$, which can be integrated into a reorganized comprehensive system thereby it could form a bridge between the natural and the built environment.

Different levels can be distinguished according to the scale of the intervention. From the smallest level to the largest: at detail scale, at building scale, on a building complex scale, at an urban scale.

By regrouping and further narrowing the sets, the appearance of water in the built environment can be divided into two large groups. One large group is represented by the "macro environment" and the other by the "micro environment", depending on its scale and spatial location.

\subsection{Macro environment}

The macro group represents a complex built environment on an urban scale, in a large, coherent natural environment. They are mostly a feature of coastline cities that expand horizontally around water. Settling on the water can also provide a solution to the new land needs of these cities, making water even more important, a key factor in developing sustainable cities (e.g., Amsterdam).

Near-water cities can be divided into five subcategories based on their relation to water: water cities, island cities, coastal cities, lakeside cities, and river cities (Fig. 4).

Where a city is partially or completely settled on water, they conduct major commercial activities in their area through their ports and canals. These cities are basically made up of a spatial network of islands, complete with built elements, mostly for shipping. Not only is the form of transport special in these cities, but because of the water implications, they have houses with special construction technology, adapting to the environmental conditions. For example: Venice, Amsterdam, Hamburg, Copenhagen, St. Petersburg, Suzhou, Cape Coral, etc.

Unlike water cities, island towns are partly or entirely based on one or more large islands. These islands are navigable, so they are lined with trade routes from which they carry out traffic and exchange of goods through their coastal ports. Surprisingly, several metropolises are built on islands (e.g., Montreal, New York, Tokyo, Hong Kong, etc.).

For coastal cities, the coastline is the dominant organizing force. They function as commercial centers through their ports, but they also display recreational functions closely linked to the shoreline. The city is surrounded by important trade routes from both the mainland and the water. Cities like Barcelona, Dubai, Lisbon, Los Angeles, Tel Aviv, Rio de Jainero, etc.

Lakeside towns are similar to coastal towns in terms of their location on the water, but there are differences in how they function - depending on the size of the lake. The waterfront, without the strong tide, favors more direct, water-friendly urban design. Examples of lakeside towns: Lausanne, Geneva, Como, Chicago, Toronto, Detroit, etc.

Last but not least, one of the most common urban designs is river towns. Their peculiarity is that the city or part of the city is permeated by the surface of the water, thus creating a very unique and distinctive city structure in each city. Along the river, coupled with commercial and industrial activities, there are decorative focus points, which create a linear routing and facade of the city, such as London, Budapest, Paris, Rome, Ottawa, Seoul, etc.

\subsection{Micro environment}

The micro group consists of smaller-scale architectural works that respond to the natural environment and live in a kind of symbiosis. The scale of buildings involving waterarchitectural interventions predicts the method of detailing required. There are three types: building in nature, water in building, and water analogy.

The building can be settled in nature in many forms, depending on the location of the water surface. The building can be adapted to the natural environment in different ways, and as a result, the relationship between the water surface and the urban "cell"/element results in a multiplicity of spatial relationships.

Based on the relationship between the building and the water surface, 11 spatial formulas can be distinguished (Fig. 5), which can be grouped into three groups according to their behavior. Buildings built on top of a mountain, over the sea, on the shore, or on a rock face have a visual connection with water. Buildings close to the water can be located in peninsulas, islands, stretching into the water or even flood plains. Aquatic buildings that have a direct physical connection can be water-based, floating, or submerged.

Water can appear in the building in many forms and functions. It can serve esthetic or representational purposes that stem from the architectural concept. It has a wide range of functions ranging from micro-climatic control to sporting purposes to acoustic elements. It can be further subdivided in terms of the origin of the water, whether natural

\section{Macro environment}

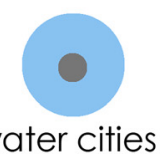

water cities
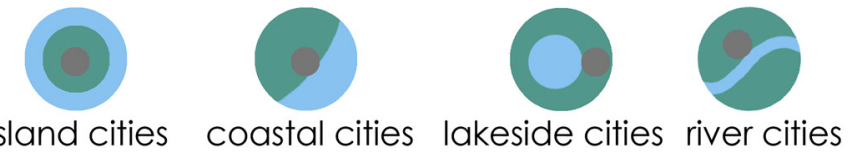

Fig. 4. Subcategories of "macro environment group" (Source: created by G. Heckenast) 


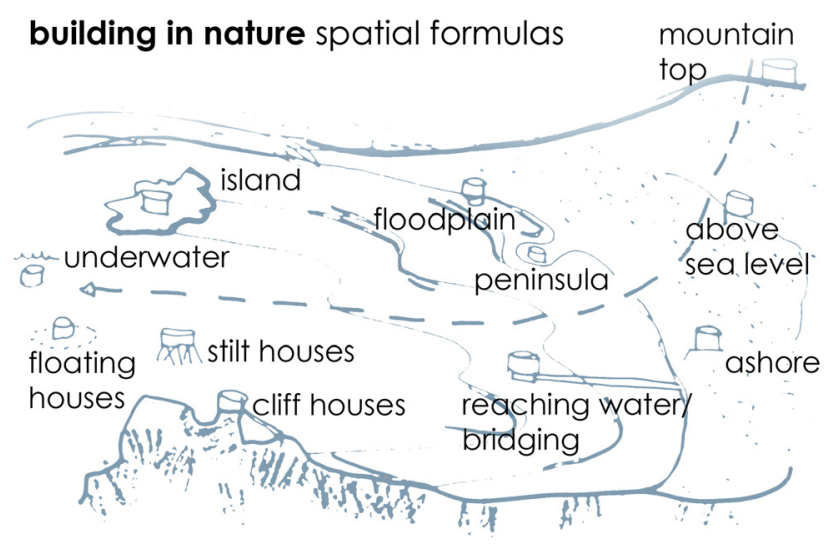

Fig. 5. Spatial formulas of buildings in nature (Source: created by G. Heckenast)

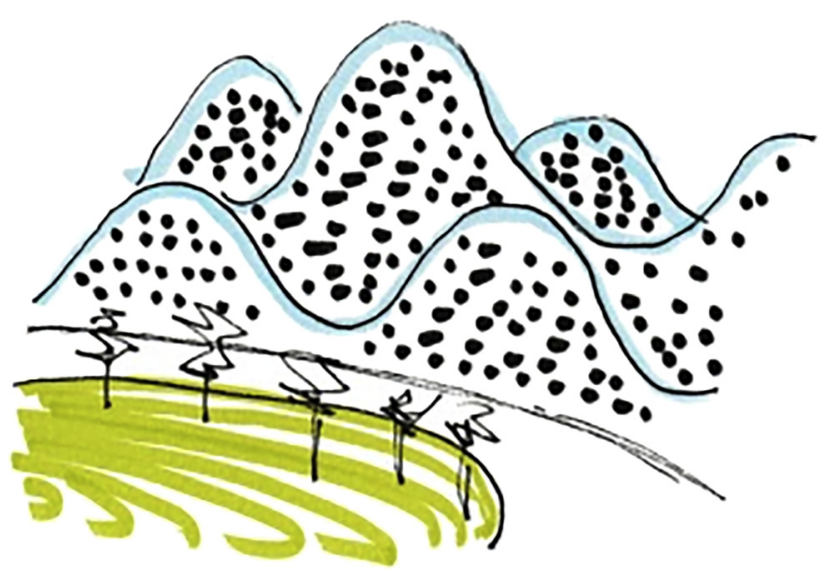

Fig. 6. Water analogy in architecture (Source: drawn by G. Heckenast)

(e.g., under the Opera House in Paris) or artificial, including pools, fountains.

Water, both indoors and outdoors, has a great impact on architecture through its physical presence.

The third group, within the micro category, is the analogy of water, which deals with the indirect presence of water. The adoption and adaptation of certain properties of water that are inherent in the nature of water itself can be achieved even when the water, as a physical element, is not present in the built environment. There are several architectural tools that can be used to make a reference to water: whether it is a spatial design, a façade, or a material.

There are an abundance of water analogs that take many forms: wave (Fig. 6), vortex, bubble, levitation, flow, crystal, or even a zoomorphic shape (marine animals).

Water analogies like flowing spaces or fluid architecture, do not just physically connect with water, but map the water itself and translate it into language of architectural space.

\section{CONCLUSION}

The architectural mindset was greatly influenced by water, not only its physical presence but also intellectually. By exploring the relationship between water and architecture it becomes more understandable the potential and dangers of water in architectural terms. Tracing the metamorphosis of water in architectural thinking can open up new opportunities in contemporary architecture from a technological and philosophical point of view, whether it is the inheritance of our built heritage or the creation of a new architectural work responding to the ever-changing circumstances. The aim of the research is to create a mind map of architectural thinking through the different aspects, which could be a theoretical basis for a detailed design method of the existing or future built environment as an answer to the upcoming challenges in the interest of living harmony with the nature.

\section{REFERENCES}

[1] I. Kiss and A. Reith, "Architectural and urban design tools for reducing energy consumption in cities," Pollack Period., vol. 8, no. 3, pp. 151-161, 2013.

[2] Sz. Portschy, "Community participation in sustainable urban growth, case study of Almere, The Netherlands," Pollack Period., vol. 11, no. 1, pp. 145-155, 2016.

[3] Z. Ryan, Building with Water: Concepts Typology Design. Birkhäuser Architecture, 2010.

[4] Shackle adventure therapy sailing school for disabled and non-disabled children. [Online]. Available: http://epiteszforum.hu/elmenyterapiasvitorlasiskola-heckenast-gabor-diplomaterve. Accessed: Dec. 23, 2019.

[5] O. Herwig and A. Thallemer, Water: Unity of Art and Science. Arnoldsche Verlagsanstalt, 2008.

[6] Ned Kahn Studios. [Online]. Available: http://nedkahn.com/. Accessed: Dec. 23, 2019.

[7] M. Fazio, M. Moffett, and L. Wodehouse, A World History of Architecture. Laurence King Publishing, 2013.

[8] L. Steg and J. I. M. de Groot, Environmental Psychology. WileyBlackwell, 2018.

[9] L. Margolis and A. Chaouni, Out of Water: Design Solutions for Arid Regions. Birkhauser, 2015.

[10] R. Barker and R. Coutts, AquaTecture: Buildings and Cities Designed to Live and Work with Water. RIBA Publishing, 2016.

[11] A. Lohrer, Basic Designing with Water. Birkhauser, 2008.

[12] I. Irving, Ed. 1001 Buildings you Must See before you Die. The World's Architectural Masterpieces, Universe, 2007.

[13] N. Spiller, Digital Architecture Now. Thames \& Hudson, 2009.

[14] A. Wylson, Aquatecture: Architecture and Water. Architectural Press, 1986.

[15] M. Prominski, A. Stokman, S. Zeller, D. Stimberg, and H. Voermanek, River, Space, Design. Birkhauser, 2017.

Open Access. This is an open-access article distributed under the terms of the Creative Commons Attribution 4.0 International License (https://creativecommons.org/ licenses/by/4.0/), which permits unrestricted use, distribution, and reproduction in any medium, provided the original author and source are credited, a link to the CC License is provided, and changes - if any - are indicated. (SID_1) 